\title{
Diffuse large B-cell non-hodgkin lymphoma of the ear with intracranial invasion
}

\author{
Alberto Guakil-Haber ${ }^{1}$, Erasmo González-Arciniega ${ }^{1}$, Benjamin García-Enríquez ${ }^{1}$, \\ María Y. Olvera-Suarez ${ }^{1}$, Enrique Segovia-Forero ${ }^{1}$, Raymundo Munguía-Vázquez ${ }^{2,3}$
}

\author{
Department of Otolaryngology and Head and Neck Surgery, ${ }^{1}$ Centro Médico ISSEMyM, Universidad Autónoma del \\ Estado de México, Toluca, Estado de México, México, ${ }^{2}$ Indiana University School of Medicine-West Lafayette, \\ Indiana, USA \\ ${ }^{3}$ Speech, Language \& Hearing Sciences, Purdue University, Indiana, USA
}

Received: 01 September 2018

Revised: 31 October 2018

Accepted: 03 November 2018

\section{*Correspondence:}

Dr. Alberto Guakil Haber,

E-mail: drguakil@gmail.com

Copyright: (C) the author(s), publisher and licensee Medip Academy. This is an open-access article distributed under the terms of the Creative Commons Attribution Non-Commercial License, which permits unrestricted non-commercial use, distribution, and reproduction in any medium, provided the original work is properly cited.

\begin{abstract}
We report a 62-year-old woman with primary diffuse large B-cell lymphoma (DLBCL) of the ear. The patient presented with facial palsy, left ear hearing loss and a mass in the left external auditory canal. CT and MRI showed an occupied external auditory canal, middle ear and temporal bone with extensive intracranial invasion, R-CHOP therapy was started, but she died after one course. Primary lymphoma of the ear is extremely rare and to the best of our knowledge this is the first case reported in a Mexican medical center, and also the first overall with such an extensive invasion.
\end{abstract}

Keywords: Primary lymphoma, Temporal bone, Ear, External auditory canal, Diffuse large B-cell lymphoma, Intracranial invasion

\section{INTRODUCTION}

Lymphomas account for the third most frequent malignant tumor of the head and neck, following squamous cell carcinoma and thyroid carcinoma, but these neoplasms are rarely present in the temporal bone, in such cases usually associated to an immunocompromised patient. $^{1}$ Approximately 23\% percent of non-Hodgkin (NHL) and $4 \%$ of Hodgkin lymphomas (HL) of the head and neck are extranodal, and mainly involve the following sites: Waldeyer's ring, paranasal sinuses, nasal and oral cavities and the salivary glands. Cases of isolated temporal bone lymphomas come from either metastatic foci, distant primaries or invasion from contiguous locations. ${ }^{1-3}$
Diffuse large B-cell lymphoma (DLBCL) is the most common type of malignant lymphoma, representing 30$40 \%$ of cases in adults. Lymphoma of the ear are rarely reported. We report a case of primary B-cell lymphoma involving the external auditory canal, middle ear and temporal bone, a site rarely reported and a review of the literature. $^{4,5}$

\section{CASE REPORT}

A 62-year-old woman with past medical history of type 2 diabetes, systemic arterial hypertension and vitiligo presented for evaluation of a four-month history of left facial palsy, left ear progressive hearing loss, tinnitus, aural fullness and severe otalgia. She denied B symptoms (weight loss, fever, night sweats). In the preceding three months she was treated by family practitioner for acute 
otitis media with clarithromycin and local ciprofloxacin. Despite treatment, her symptoms deteriorated and referral to our otolaryngology department was made.

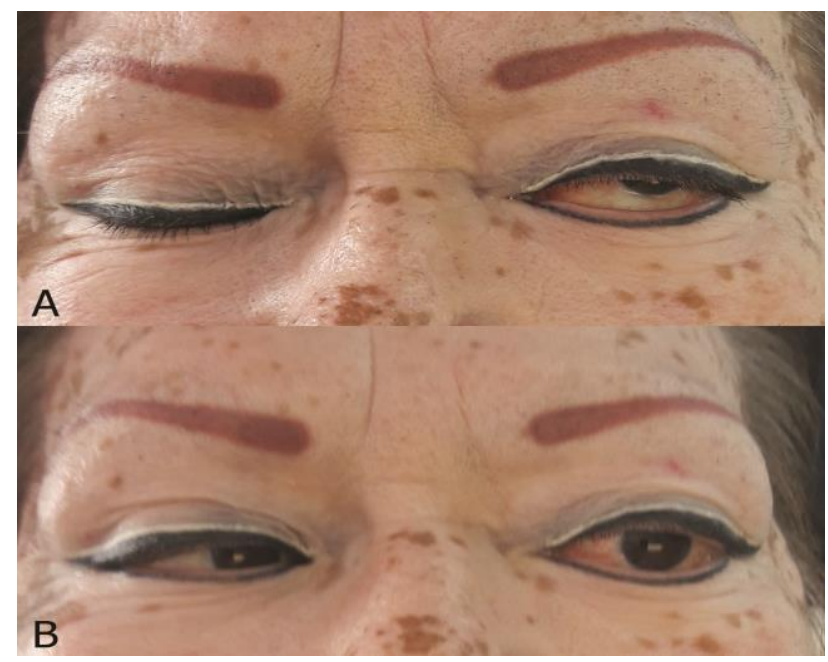

Figure 1: (A) Incomplete palpebral closure (Bell's phenomenon); (B) VI C.N. paralysis left eye.

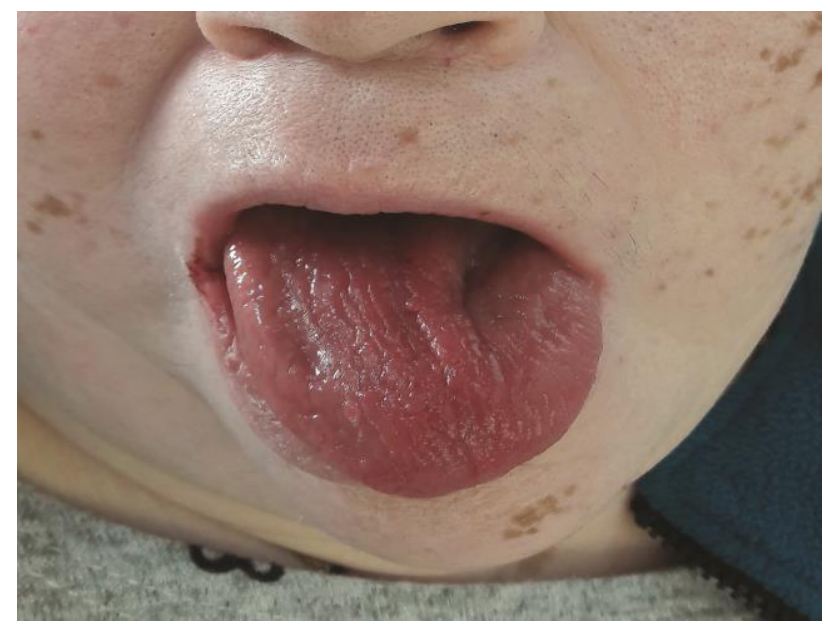

Figure 2: Hypoglossal nerve paralysis.

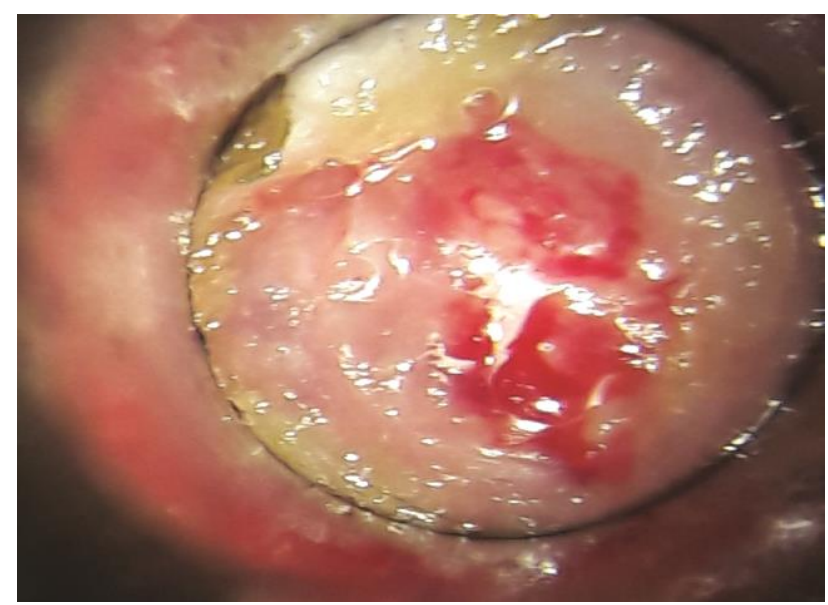

Figure 3: Left otoscopy showing a mass filling the external auditory canal.
On examination she had left-sided facial nerve palsy (Grade IV House-Brackmann classification) and absent left eye movements (Figure 1 A, B). Hypoglossal nerve palsy was also found (Figure 2). Otoscopy of the left ear showed a round, pale, sessile, mobile, friable, nonpulsatile mass filling two thirds of the external auditory canal (Figure 3). Tuning fork and audiometry test confirmed an anacusic left ear.

Laboratory studies on admission showed a white blood cell count of $4.57 \times 10^{3} / \mu \mathrm{L}$, hemoglobin of $8.0 \mathrm{~g} / \mathrm{dl}$, hematocrit of $27.8 \%$, and platelet count of $180 \times 10^{3} / \mu \mathrm{L}$, with progressive descent showing pancytopenia four days later with a white blood cell count of $1.21 \times 10^{3} / \mu \mathrm{L}$, hemoglobin of $7.1 \mathrm{~g} / \mathrm{dl}$, hematocrit of $25.2 \%$, and platelet count of $91 \times 10^{3} / \mu \mathrm{L}$. C-reactive protein (CRP) was 40.28 $\mathrm{mg} / \mathrm{L}$ (normal value less than $10 \mathrm{mg} / \mathrm{L}$ ) and erythrocyte sedimentation rate of $19 \mathrm{~mm} / \mathrm{hr}$ (normal value less than $30 \mathrm{~mm} / \mathrm{hr}$ ). Anti-hepatitis C virus antibody, hepatitis B surface antigen and anti-human immunodeficiency virus antibodies were negative.

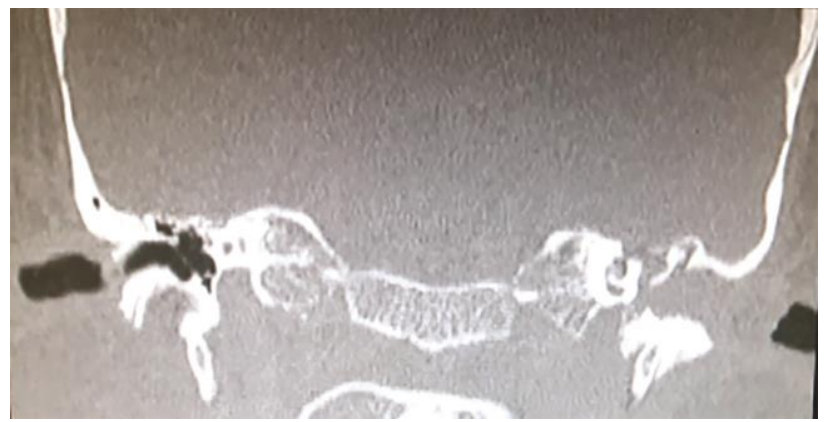

Figure 4: Coronal CT scan showing a soft tissue density opacification of the external auditory canal and middle ear, with erosion of the tegmen tympani is also noted.

Computed tomography (CT) of the left ear showed homogenous opacification of the mastoid cells, tympanic cavity and external auditory canal, erosion of the tegmen tympani, tegmen mastoideum (Figure 4), petrous apex, carotid canal, lesser sphenoidal wing and petroclival articulation was also noted.

Multiple biopsies were taken under local anesthesia, which were reported as cholesteatoma and lymphoid cell groups in a diffuse pattern with necrotic areas, but histological examination was inconclusive (Figure 5) Immunohistochemical studies revealed a positive CD20, BCL2 (100\%), Ki67 (70\%) and negative Cytokeratin AE1/AE3, monoclonal anti-episialin antibody and ALK, suggesting a non-Hodgkin's lymphoma classified as diffuse large B-cell lymphoma.

A bone marrow aspiration and biopsy showed primarily hematopoietic cells with less than $5 \%$ blasts and lymphocytes, with no increase in plasma cells. B-cells accounted for $2-3 \%$ of cellularity and showed 
heterogeneous Kappa expression. A normal 46, XX karyotype was reported. Magnetic resonance imaging (MRI) of the head revealed a large irregular, heterogeneous mass with low signal intensity on T1weighted, destroying the left temporal bone, occupying the middle ear and external auditory canal, and involving the cavernous sinus, temporal lobe, mesencefalus and pons, an important contrast uptake was noted. The lesion showed intermediate signal intensity on T2-weighted images, while mastoid air cells showed high signal intensity corresponding to effusion (Figure 6).

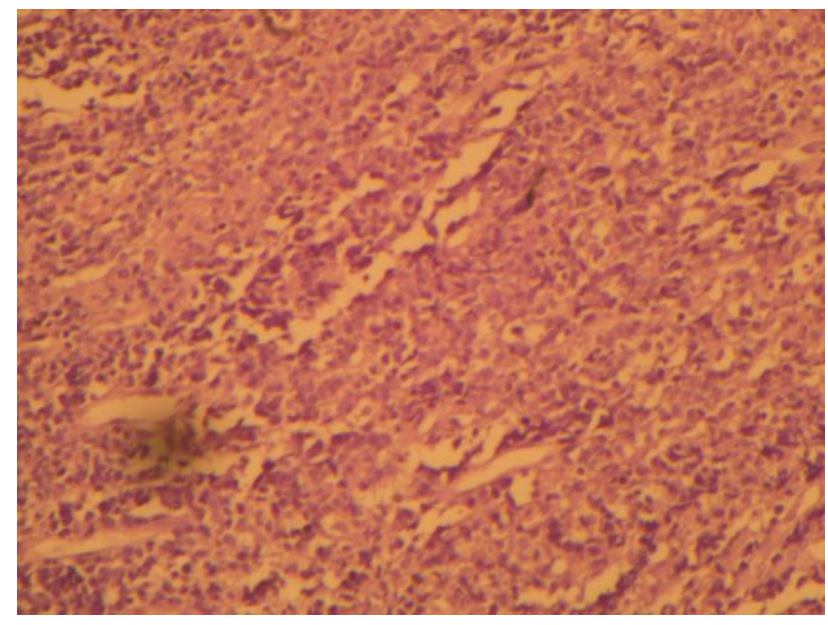

Figure 5: Lymphoid cell groups in a diffuse pattern with necrotic areas.

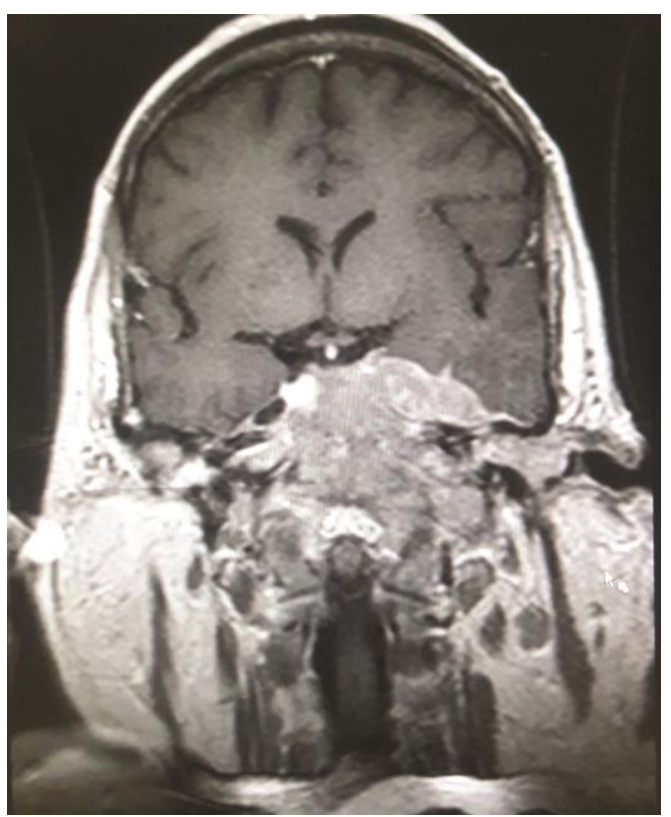

Figure 6: T1-weighted Coronal MRI illustrating extensive enhancing mass filling the right external auditory canal, middle-ear cleft and mastoid, with intracranial extension.

The patient was referred to an Oncologic Center where a F18-FDG PET scan was taken showing an irregular high signal lesion in the middle ear and external auditory canal, left temporal lobe and cerebellum, involving the ipsilateral masticator and pharyngeal mucosal space (Figure 7). Further investigation revealed involvement of lymph nodes in both sides of the diaphragm, and extranodal sites (lungs, liver, psoas, peritoneum) were also noted.

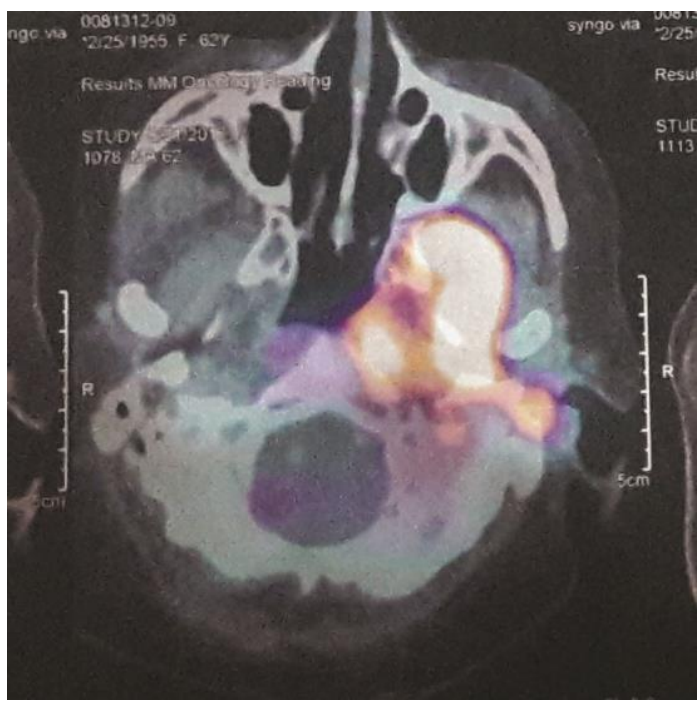

Figure 7: High signal lesion in the middle ear and external auditory canal, left temporal lobe and cerebellum.

The patient was admitted at the Oncologic Center where she was classified according to the Ann Arbor classification as a stage $\mathrm{IV}_{\mathrm{E}}$. She started chemotherapy with R-CHOP scheme (Cyclophosphamide, adriablastin, vincristine, rituximab, and methylprednisolone). She died 3 weeks after being admitted, after receiving 1 cycle of cyclophosphamide.

\section{DISCUSSION}

Lymphomas are very common malignancies of the head and neck, most commonly present as asymptomatic lymphadenopathies, 60-80\% occurring in the cervical and supraclavicular nodes, or presenting B symptoms: fever, unexplained weight loss and night sweats, in up to $50 \%$ of patients with advanced disease. However, in our case, as mentioned before, the patient did not present any of these symptoms. ${ }^{1,6}$

Lymphomas in the ear and temporal bone are usually due metastatic foci or invasion from contiguous locations as was commented, but primary lymphomas of the ear are exceedingly rare, therefore histological and clinical features have not been extensively characterized.

The nature of the lesion can be characterized by contrast enhanced TC and MRI, but a definite diagnosis must be histopathological. $^{7}$

Staging for HL and NHL is based on the Ann Arbor classification. Stage I consists in involvement or a single 
lymph node or extranodal site in the absence of any lymph node involvement. Stage II involves two or more lymph node regions on the same side of the diaphragm or involvement of a single extralymphatic organ or site in association with regional lymph node involvement. Stage III involves lymph node regions on both sides of the diaphragm, extralymphatic extension accompanied by lymph node involvement or involvement of the spleen. Stage IV is characterized by diffuse or disseminated involvement of one or more extralymphatic organs, with or without lymph node involvement. ${ }^{8}$

Table 1: List of primary lymphoma of the ear case reports.

\begin{tabular}{|c|c|c|c|c|c|c|c|c|}
\hline Case & Year & Author & Age & Sex & Localization & Immunophenotype & Therapy & Outcome \\
\hline 1 & 1976 & Malik et al. ${ }^{13}$ & 6 & M & ME & Lymphocytic & $\mathrm{S}$ & $\begin{array}{l}\text { Relapse, } \\
\text { lost }\end{array}$ \\
\hline 2 & 1980 & Harner et al. $^{14}$ & 66 & M & ME & Lymphocytic & CT & Dead \\
\hline 3 & 1980 & $\begin{array}{l}\text { Gapany-Gapanavicius } \\
\text { et al. }{ }^{15}\end{array}$ & 32 & $\mathrm{~F}$ & ME, TB & Nodular, histiocytic & $\mathrm{S}, \mathrm{CT}, \mathrm{RT}$ & Dead \\
\hline 4 & 1981 & Oyetunji \& Ladapo $^{16}$ & 7 & $\mathrm{M}$ & TB & Burkitt, B-cell & CT & Dead \\
\hline 5 & 1987 & Conley et al. ${ }^{8}$ & - & - & TB & NHL & Unknown & Unknown \\
\hline 6 & 1987 & Welling \& $\mathrm{McCabe}^{17}$ & 6 & $\mathrm{M}$ & $\mathrm{ME}$ & Burkitt, B-cell & $\mathrm{S}, \mathrm{CT}$ & Alive \\
\hline 7 & 1988 & Toriumi et al. ${ }^{18}$ & 76 & $\mathrm{M}$ & ME & DLBCL & Unknown & Unknown \\
\hline 8 & 1991 & Maiche et al. ${ }^{19}$ & 71 & $\mathrm{M}$ & EAC (bil) & Diffuse centrocytic & $\mathrm{CT}$ & Alive \\
\hline 9 & 1992 & Tucci et al. ${ }^{20}$ & 66 & M & TB & DLBCL & S, CT, RT & Dead \\
\hline 10 & 1992 & Tucci et al. ${ }^{20}$ & 5 & $\mathrm{M}$ & TB & DLBCL & CT & Alive \\
\hline 11 & 1993 & Ide et al. ${ }^{21}$ & 55 & $\mathrm{M}$ & ME & Pleomorphic, T-cell & $\mathrm{CT}, \mathrm{RT}$ & Dead \\
\hline 12 & 1993 & Noguchi et al. ${ }^{22}$ & 40 & $\mathrm{M}$ & TB & DSBCL & $\mathrm{CT}, \mathrm{RT}$ & Alive \\
\hline 13 & 1995 & Bockmuhl et al. ${ }^{23}$ & 2 & $\mathrm{M}$ & TB & Blastic, B-cell, EBV+ & $\mathrm{S}, \mathrm{CT}$ & Alive \\
\hline 14 & 1997 & Saigusa et al. ${ }^{24}$ & 66 & $\mathrm{~F}$ & TB & $\begin{array}{l}\text { DLBCL, } \\
\text { immunoblastic }\end{array}$ & RT & Dead \\
\hline 15 & 1997 & Danino et al..$^{25}$ & 16 & M & ТВ & $\begin{array}{l}\text { Large T-cell, } \\
\text { immunoblastic }\end{array}$ & $\mathrm{CT}, \mathrm{RT}$ & Dead \\
\hline 16 & 1998 & Angeli et al. ${ }^{26}$ & 56 & $\mathrm{~F}$ & IAC & Large B-cell & $\mathrm{S}, \mathrm{CT}, \mathrm{RT}$ & Alive \\
\hline 17 & 2000 & Merkus et al. ${ }^{10}$ & 83 & $\mathrm{~F}$ & EAC & Anaplastic large cell & RT & Alive \\
\hline 18 & 2000 & Merkus et al. ${ }^{10}$ & 75 & M & $\begin{array}{l}\text { TB, ME, } \\
\text { EAC }\end{array}$ & DLBCL & $\mathrm{CT}, \mathrm{RT}$ & Alive \\
\hline 19 & 2002 & Fish et al. $^{12}$ & 53 & $\mathrm{~F}$ & EAC & DLBCL & $\mathrm{S}, \mathrm{CT}$ & Alive \\
\hline 20 & 2002 & Shuto et al. ${ }^{27}$ & 49 & M & EAC (bil) & $\begin{array}{l}\text { B-cell small } \\
\text { lymphocytic }\end{array}$ & $\mathrm{S}, \mathrm{CT}$ & Alive \\
\hline 21 & 2003 & Lang et al. ${ }^{28}$ & 5 & M & ME, TB & Lymphoblastic, B-cell & CT & Alive \\
\hline 22 & 2003 & Koral et al. ${ }^{29}$ & 15 & M & $\mathrm{TB}$ & $\begin{array}{l}\text { Diffuse histiocytic } \\
\text { large cell }\end{array}$ & $\mathrm{CT}$ & Alive \\
\hline 23 & 2004 & Chang et al..$^{30}$ & 81 & $\mathrm{~F}$ & TB & DLBCL & $\mathrm{CT}, \mathrm{RT}$ & Unknown \\
\hline 24 & 2006 & Ogawa et al. ${ }^{4}$ & 74 & $\mathrm{~F}$ & $\mathrm{~TB}, \mathrm{EAC}$ & DLBCL & $\mathrm{CT}, \mathrm{RT}$ & Alive \\
\hline 25 & 2006 & Hersh et al. $^{2}$ & 83 & $\mathrm{~F}$ & EAC & DLBCL & RT & Alive \\
\hline 26 & 2008 & González et al. $^{31}$ & 53 & $\mathrm{~F}$ & EAC & Anaplastic T-cell & $\mathrm{CT}$ & Alive \\
\hline 27 & 2009 & Liu et al. ${ }^{32}$ & 7 & $\mathrm{~F}$ & $\begin{array}{l}\text { ME, TB, } \\
\text { EAC, IE }\end{array}$ & Lymphoblastic, B-cell & $\mathrm{S}, \mathrm{CT}$ & Alive \\
\hline 28 & 2013 & Bruschini et al. $^{5}$ & 46 & $\mathrm{M}$ & EAC & DLBCL & CT & Alive \\
\hline 29 & 2015 & Ryou et al. $^{33}$ & 35 & $\mathrm{M}$ & IAC, TB & DLBCL & $\mathrm{CT}$ & Dead \\
\hline 30 & 2016 & Li et al. ${ }^{34}$ & 11 & $\mathrm{M}$ & $\mathrm{ME}$ & Lymphoblastic, T-cell & $\mathrm{CT}$ & Alive \\
\hline 31 & 2017 & Maithrea et al. $^{3}$ & 53 & M & $\begin{array}{l}\text { ME, TB, } \\
\text { EAC }\end{array}$ & Nodular sclerosis HL & CT & Alive \\
\hline
\end{tabular}

ME: Middle ear, TB: Temporal bone, EAC: External auditory canal, IAC: Internal auditory canal, IE: Inner ear.

The differential diagnosis of an external auditory canal masses is commonly benign, including cholesteatoma, adenoma, exostoses and osteoma, malignant tumors are uncommon, typically limited to squamous cell carcinoma, but basal cell carcinoma, melanoma and adenocarcinoma can also arise. Middle ear neoplasms include glomus tympanicum, glomus yugulare, adenoma, rhabdomyosarcoma, osteosarcoma, lymphoma, adenocarcinoma, melanoma, and metastatic lesions, while inner ear, petrous apex and cerebellopontine angle 
presents benign tumors like vestibular schwannomas, nonvestibular cranial nerve schwannomas, meningiomas and lipomas, malignant tumors are rare, the most common is chondrosarcoma of the skull base. ${ }^{9}$

According to Schuknecht, the mucosa of the mastoid antrum, tympanum, or the tympanic orifice of the eustachian tube have a layer of lymphoid tissue deep to the epithelium and can a site for lymphoma. ${ }^{10}$

Extranodal lymphoma is extremely rare, retrospective studies report an incidence of 1.9 to 11.4 cases per year. It has a peak incidence in the 6th and 7 th decades, with a median age of 68, although it can affect all ages and more often in males. The head and neck is the second most common site of presentation of extra nodal lymphomas behind the abdomen. ${ }^{1,11,12}$

We found only 31 reported cases of primary lymphoma of the ear in the international literature, detailed in Table 1. Men (64\%) being more affected than women (36\%). The age at diagnosis ranged from 2 to 83 years with a tendency for pediatric and elderly populations. Otologic symptoms such as otalgia, otorrhea, hearing loss, and ear fullness were the more common. Facial nerve palsy was present at diagnosis in 8 of 32 patients, including our case, however there were no cases reported of associated cranial nerve paralysis other than the facial and vestibulocochlear nerves, meanwhile our patient had paralysis of the III, IV, IV and XII cranial nerves. On otoscopic examination, 11 patients, had a mass in the external auditory canal, in only 4 of them, including our patient, the tumor extended beyond the external auditory canal. The most frequent immunophenotype was B-cell type in 19 of 32 patients (59\%).

Treatment of diffuse large B-cell lymphoma is primarily multiagent chemoradiation. In this patient an R-CHOP scheme was initiated but the patient died after 1 cycle of cyclophosphamide.

We report a rare case of primary lymphoma involving the external auditory canal, middle and inner ear with intracranial invasion, which to our knowledge and revision of the literature hasn't been described before, also this is the first case described in a Mexican patient.

Our case and a review of the literature show the natural history of an untreated malignant lymphoma and this should be taken into consideration as a differential diagnosis in cases of therapy-resistant ear disease.

\section{CONCLUSION}

Primary lymphoma of the ear is extremely rare and to the best of our knowledge this is the first case reported in a Mexican medical center, and also the first overall with such an extensive invasion at diagnosis. In cases of therapy-resistant ear disease or peripheral facial paralysis a benign or malignant tumor should be excluded by computed tomography. These patients have a progressive and deteriorating course that goes from weeks to months, and biopsy should be taken for diagnosis. Uniform therapy this disease not been established. Radical tumor resection is discouraged, as it sacrifices vital structures and typically doesn't increase survival rates. Recent therapy attempts are focusing on multiagent chemoradiation as the primary modality.

\section{Funding: No funding sources \\ Conflict of interest: None declared \\ Ethical approval: Not required}

\section{REFERENCES}

1. Picard A, Cardinne C, Denoux Y, Wagner I, Chabolle F, Bach CA. Extranodal lymphoma of the head and neck: A 67-case series. Eur Ann Otorhinolaryngol Head Neck Dis. 2015;132(2):715 .

2. Hersh S, Harrison W, David H. Primary B Cell lymphoma of the external auditory canal. Ear, Nose Throat J. 2006;85(9):597-9.

3. Maithrea N, Periyathamby S, Mohamad I. Primary Hodgkin's lymphoma of the middle ear: A rare cause of facial nerve palsy. Egypt $\mathrm{J}$ Ear, Nose, Throat Allied Sci. 2017;18(1):67-9.

4. Ogawa S, Tawara I, Ueno S, Kimura M, Miyazaki $\mathrm{K}$, Nishikawa $\mathrm{H}$, et al. De novo CD5-positive diffuse large B-cell lymphoma of the temporal bone presenting with an external auditory canal tumor. Intern Med. 2006;45(11):733-7.

5. Bruschini L, De Vito A, Fortunato S, Pelosini M, Cervetti G, Petrini M, et al. A Case of Primary NonHodgkin's Lymphoma of the External Auditory Canal. Case Rep Otolaryngol. 2013;2013:1-4.

6. Schmedes GW, Rizk HG, Lambert PR. Middle ear mass with facial weakness. Diffuse large B-cell lymphoma of the middle ear. JAMA Otolaryngol Head Neck Surg. 2015;141(1):89-90.

7. Santos Montón CGGM. Radiological findings of a primary middle-ear lymphoma in a 8 -year-old boy. Cart Cien. 2015;268-70.

8. Conley SF, Staszak C, Clamon GH, Maves MD. Non-Hodgkin's lymphoma of the head and neck: the University of Iowa experience. Laryngoscope. 1987;97(3 Pt 1):291-300.

9. Dubernard X, Kleiber JC, Brenet E, Louges MA, Veleine Y, Labrousse M, et al. Tumors of the ear. Press Medicale. 2017;46(11):1079-88.

10. Merkus P, Copper MP, Van Oers MHJ, Schouwenburg PF. Lymphoma in the ear. Orl. 2000;62(5):274-7.

11. Vega F, Lin P, Medeiros LJ. Extranodal lymphomas of the head and neck. Ann Diagn Pathol. 2005;9(6):340-50.

12. Fish BM, Huda R, Dundas SAC, Lesser THJ. B-cell lymphoma of the external auditory meatus. J Laryngol Otol. 2002;116(1):39-41. 
13. Malik MK, Gupta RK, Samuel KC. Primary lymphoma of middle ear - a case report. Indian J Cancer 1976;13:188-9.

14. Harner SG, Olsen KD, Banks PM, O'Connell MJ. Lymphocytic lymphoma involving the middle ear. Mayo Clin Proc 1980;55:645-7.

15. Gapany-Gapanavicius BG, Chisin R, Weshler Z: Primary presentation of malignant lympho- ma in the middle ear cleft. A case report. Ann Otol. 1980;89:180-3.

16. Oyetunji NMA, Ladapo AA: Burkitt's lympho- ma of the mastoid temporal bone. J Laryngol Otol 1981;95:1063-7.

17. Welling DB, McCabe BF: American Burkitt's lymphoma of the mastoid. Laryngoscope 1987;97:1038-42.

18. Toriumi DM, Friedman CD, Allen GW: Pathological quiz case 2. Malignant lymphoma, diffuse large cell type. Arch Otolaryngol Head Neck Surg 1988;114:1330-3.

19. Maiche AG, Teerenhovi L, Isokangas O: Dif- fuse centrocytic malignant lymphoma with unusual sites. Report on two cases with possible etiological factors. Acta Oncol 1991;30:767-8.

20. Tucci DL, Lambert PR, Innes DJ Jr. Primary lymphoma of the temporal bone. Arch Otolaryngol Head Neck Surg 1992;118:83-5.

21. Ide M, Matsuura K, Imuta M. Primary malignant lymphoma of middle ear. Otol Jpn 1993;3:199-202.

22. Noguchi H, Motizuki T, Kamata T, Ogawa Y, Ueno Y. Primary malignant lymphoma in the temporal bone -report of a case. Jibi Inkoka, Tokeibu Geka 1993;65:757-60.

23. Bockmuhl U, Bruchhage KL, Enzmann H. Primary non-Hodgkin's lymphoma of the temporal bone. Eur Arch Otorhinolaryngol. 1995;252:376-8.

24. Saigusa H, Akimoto R, Ryu A, et al. Malignant lymphoma of the temporal bone. Jibi Inkoka, Tokeibu Geka. 1997;69:233-8.

25. Danino J, Joachims HZ, Ben-Arieh Y, Hefer T, Weyl-Ben-Arush M. T cell lymphoma of the ear presenting as mastoiditis. J Laryngol Otol. 1997;111:852-4.
26. Angeli SI, Brackmann DE, Xenellis JE, Poletti BJ, Carberry JN, Hitselberger WE. Primary lymphoma of the internal auditory canal. Case report and review of the literature. Ann Otol Rhinol Laryngol. 1998;107(1):17-21.

27. Shuto J, Ueyama T, Suzuki M, Mogi G. Primary lymphoma of bilateral external auditory canals. Am J Otolaryngol Head Neck Med Surg. 2002;23(1):49-52.

28. Lang EE, Walsh RM, Leader M. Primary middle-ear lymphoma in a child. $\mathrm{J}$ Laryngol Otol. 2003;117(3):205-7.

29. Koral K, Curran JG, Thompson A. Primary nonHodgkin's lymphoma of the temporal bone. CT findings. Clin Imaging. 2003;27:386-8.

30. Chang CY, O'Halloran EK, Fisher SR. Primary non-Hodgkin's lymphoma of the petrous bone: case report. Otolaryngol Head Neck Surg. 2004;130:3602.

31. Gonzalez Delgado A, Argudo Marco F, Sanchez Martinez N, Sprekelsen Gasso C. T Cell NonHodgkin's Lymphoma of the External Auditory Canal. Acta Otorrinolaringol Esp. 2008;59(4):2001 .

32. Liu, Yen-Lin, Tung C-L. Precursor B-Cell Lymphoblastic Lymphoma of the Ear in a 7-YearOld Child. J Clin Oncol. 2009;27(16):2726-8.

33. Ryou N, Ko DY, Jun HJ, Chae SW. Lymphoma of the internal auditory canal presenting as facial palsy, vertigo, and hearing loss. J Int Adv Otol. 2015;11(3):262-3.

34. Li B, Liu S, Yang H, Wang W. Primary T-cell lymphoblastic lymphoma in the middle ear. International Journal of Pediatric Otorhinolaryngology. 2016;82:19-22.

Cite this article as: Guakil-Haber A, GonzálezArciniega E, García-Enríquez B, Olvera-Suarez MY, Segovia-Forero E, Vázquez-Munguía R. Diffuse large B-cell non-hodgkin lymphoma of the ear with intracranial invasion. Int J Otorhinolaryngol Head Neck Surg 2019;5:193-8. 